\title{
Környezeti hatások a gyermekkori kezdetú, l-es típusú diabetes epidemiológiai változásainak hátterében
}

\author{
Tények és feltevések \\ Lukács Krisztina dr. - Pánczél Pál dr. - Hosszúfalusi Nóra dr. \\ Semmelweis Egyetem, Általános Orvostudományi Kar, Belgyógyászati és Hematológiai Klinika, Budapest
}

\begin{abstract}
A Nemzetközi Diabetes Szövetség (International Diabetes Federation, IDF) legutóbbi becslése szerint napjainkban több mint 600 000, 15 év alatti l-es típusú cukorbeteg gyermek él a világon, az új esetek száma pedig évi 98 200-ra tehető. Az elmúlt évtizedekben az l-es típusú diabetes incidenciája világszerte jelentősen nőtt ebben a korosztályban: Európában az 1989 és 2013 közötti periódusban átlagosan évi 3,4\%-kal, ami 20 éven belül a betegek számának duplázódását vetíti előre a kontinensen. Az epidemiológiai vizsgálatok kezdete óta nyilvánvaló, hogy a gyermekkori kezdetű, l-es típusú diabetes előfordulási gyakorisága széles határok között ingadozik, amit egyaránt befolyásolnak geográfiai és klímaviszonyok, etnikai és demográfiai hatások. Bár az l-es típusú cukorbetegség kialakulása során az autoimmunitás primer kockázati tényezője a genetikai háttér, mégsem a genetikai terheltség populációszintű fokozódása okozza az incidencia robbanásszerú növekedését, hanem a környezeti tényezőknek a betegség penetranciáját megváltoztató hatása. A környezeti hatások oki tényezőkként, akcelerátorokként és védőfaktorokként is hozzájárulhatnak mindehhez, sốt akár a betegség patogenezisében egyszerre több ponton, több mechanizmussal is részt vehetnek. Ugyanakkor a nemzetközi kutatások ellenére a legnépszerúbb háttérelméletek (például vírusinfekció, higiéniahipotézis, bélmikrobiom, áteresztő bél, D-vitamin-hiány) máig nem szolgálnak kielégítő magyarázattal az epidemiológiai észlelések többségére (például földrajzi régiónként jelentősen eltérő incidenciaértékek, geográfiai „forrópontok”, az új esetek megjelenésének szezonális ingadozása, az incidenciacsúcsok ciklicitása). Összefoglalónk célja a gyermekkori l-es típusú diabetes epidemiológiájára vonatkozó aktuális adatok és háttérelméletek áttekintése. Orv Hetil. 2021; 162(1): 13-22.
\end{abstract}

Kulcsszavak: gyermekkori l-es típusú diabetes, incidencia, földrajzi megoszlás, időbeli változás, környezeti faktorok

\section{Environmental factors and epidemiology of childhood type 1 diabetes}

\section{Facts and bypotheses}

According to the latest report of the IDF (International Diabetes Federation), more than 600000 children under the age of 15 years are living with type 1 diabetes in the world and the number of new cases is estimated to be 98200 annually. In recent decades, a significant increase in the incidence has been observed globally: during 1989-2013, the annual rate of increase was $3.4 \%$ in Europe, suggesting a doubling in the number of patients within approximately 20 years on the continent. The wide variation in incidence has been well documented by epidemiological studies and influenced by geographical and climatic conditions, ethnic and demographic factors. Although the genetic background is the primary risk factor for beta-cell autoimmunity, such dynamic changes in incidence are more likely to be associated with the higher environmental pressure than the increase in genetic load at population level. Environmental factors can also contribute to the pathogenesis of type 1 diabetes as accelerators, causal or protective factors, moreover may even be involved at several points and with several mechanisms at the same time. However, despite the extensive international research on environmental factors, the most popular hypotheses associated with them (e.g., virus infections, hygiene hypothesis, intestinal microbiota, leaky gut, lack of vitamin D) have not yet provided a satisfactory explanation for most epidemiological observations (e.g., geographically significant variability of incidence rates, geographical "hotspots", seasonal fluctuations in new cases, cyclical trends of incidence peaks). In this article, recent data and hypotheses about the epidemiology of childhood type 1 diabetes are summarized. 
Keywords: childhood type 1 diabetes, environmental factors, incidence, geographical distribution, temporal change

Lukács K, Pánczél P, Hosszúfalusi N. [Environmental factors and epidemiology of childhood type 1 diabetes. Facts and hypotheses]. Orv Hetil. 2021; 162(1): 13-22.

(Beérkezett: 2020. június 13.; elfogadva: 2020. július 4.)

\section{Rövidítések}

ABIS $=$ All Babies in Southeast Sweden; BCG $=$ Bacillus Calmette-Guérin; DAISY = Diabetes Autoimmunity Study in the Young; DDT = diklór-difenil-triklóretán; DERI-csoport = (Diabetes Epidemiology Research International Group) Diabetes Epidemiológia Nemzetközi Kutatócsoport; DIAMOND = Diabetes Mondiale; DNS = dezoxiribonukleinsav; EURO$\mathrm{DIAB}=$ (Europe and Diabetes) Európa és Diabetes kollaboratív kutatói hálózat; FINDIA = Finnish Dietary Intervention Trial for the Prevention of Type 1 Diabetes; GAD65 = glutaminsav-dekarboxiláz-65; H1N1, H3N2 = a hemagglutinin 1-es, illetve 3 -as és a neuraminidáz 1 -es, illetve 2 -es típusát tartalmazó vírusok; HLA = humán leukocytaantigén; HSP65 = hősokkprotein-65; IDDM = inzulindependens diabetes mellitus; IDF $=($ International Diabetes Federation $)$ Nemzetközi Diabetes Szövetség; IDM = (index of multiple deprivation) többszörös deprivatiós index; IRAP $=$ (insulin-regulated aminopeptidase) inzulinfüggő aminopeptidáz; MAP = Mycobacterium avium paratuberculosis; NF = nukleáris faktor; NOD-egér $=($ non-obese diabetic mouse $)$ nem elhízott cukorbeteg egér; $\mathrm{RXR}=$ retinoid X-receptor; TRIGR $=$ Trial to Reduce IDDM in the Genetically at Risk; VDR $=($ vitamin $\mathrm{D}$ receptor $) \mathrm{D}$-vitamin-receptor

\section{Időbeli változások és földrajzi különbségek}

A gyermekkori kezdetú, l-es típusú diabetes előfordulási gyakoriságának növekedését már az 1970-es évek elején, az epidemiológiai kutatások kezdetén felismerték. Ezt követően nemzetközi kollaboratív kutatói hálózatok alakultak, hogy a standardizált adatgyújtésen alapuló prospektív regiszterekkel képesek legyenek világszerte felmérni a cukorbetegség incidenciáját és hosszú távon követni az időbeli és térbeli változásokat.

Elsőként a DERI-csoport (Diabetes Epidemiology Research International Group) igazolta a gyermekkori l-es típusú diabetes gyakoriságának emelkedését a világ 15 országára vonatkozóan 1978 és 1988 között. A tág határok között mozgó, a szélsőértékek között mintegy hatvanszoros különbségû́ incidencia Finnországban és a skandináv régióban volt a legmagasabb, Japánban és Mexikóban a legalacsonyabb. Az eredmények alapján már ekkor felvetették a betegség előfordulásának észak-déli irányú csökkenését, de a megerősítéshez nem állt rendelkezésükre kellő számú, déli országra vonatkozó, nemzetközi összehasonlításra alkalmas adat [1].

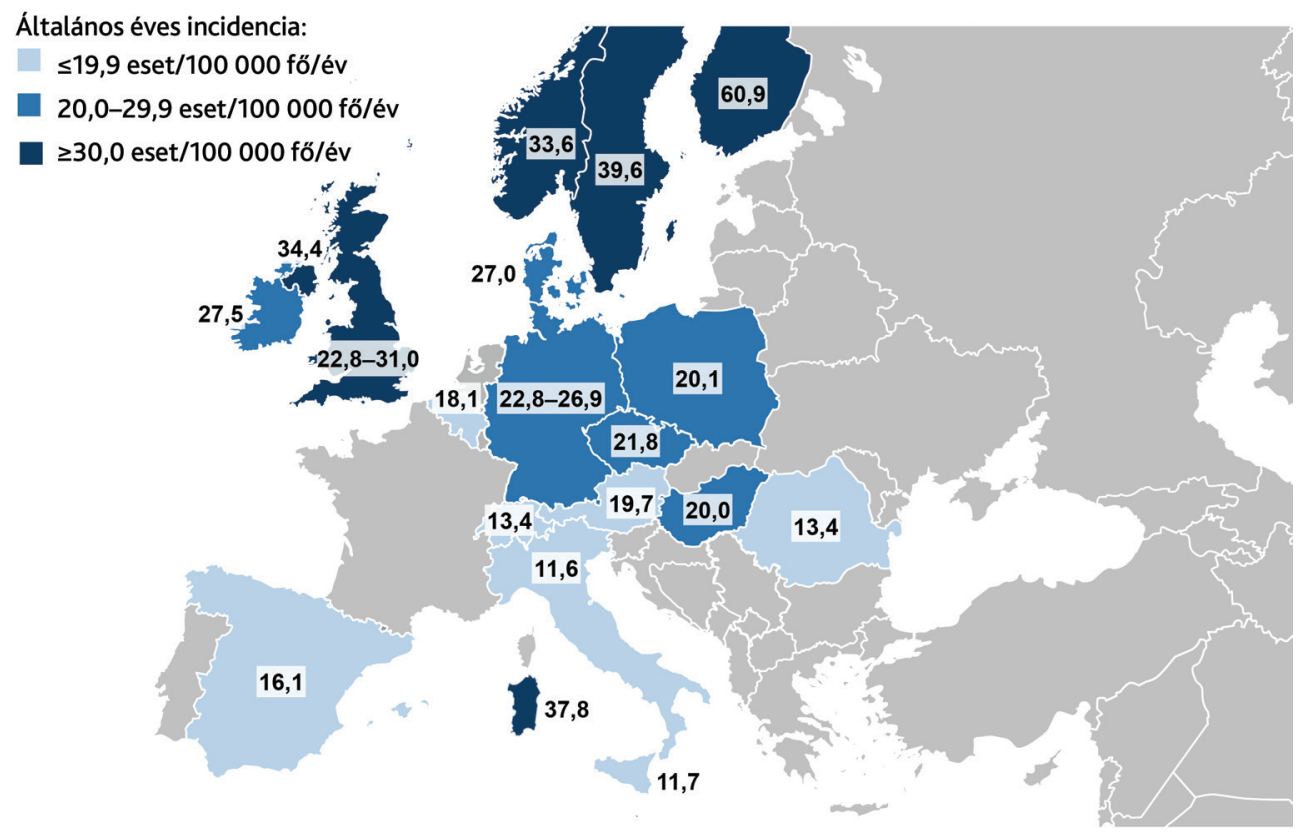

1. ábra

A gyermekkori 1-es típusú diabetes incidenciája 1989 és 2013 között Európában

Az ábra a [4] referencia felhasználásával készült 
A DIAMOND (Diabetes Mondiale) kutatói 1990 és 1999 között 57 országban vizsgálták a 15 év alatti korcsoportban az újonnan diagnosztizált, l-es típusú diabetes gyakoriságát és időbeli változását. Ekkor az l-es típusú cukorbetegség standardizált incidenciája Finnországban volt a legnagyobb (40,9 eset/100 000 fö/év), Kínában és Venezuelában a legalacsonyabb (0,1 eset/100 000 fó/év). Ezen időszak alatt az átlagos éves incidencianövekedés 2,8\% volt, 1990 és 1994 között kissé lassabb (2,4\%), majd 1995 és 1999 között gyorsabb (3,4\%) emelkedéssel. A kontinensekre vetített trendek szerint Észak-Amerikában 5,3\%, Ázsiában 4,0\%, Európában és Óceániában 3,2\% volt a növekedés mértéke; a világszerte észlelt, statisztikailag szignifikáns emelkedés alól csak Közép-Amerika jelentett kivételt, ahol 3,6\%-os csökkenést mértek [2].

Az EURODIAB (Europe and Diabetes) kollaboratív hálózat 1998-ban jött létre a gyermekkori l-es típusú cukorbetegség incidenciájának európai vizsgálatára. Az 1989 és 2003 közötti 15 éves periódusban Európában 3,9\%-os teljes éves növekedési rátát észleltek: a legnagyobb, 9,3\%-os Lengyelországban, a legkisebb, mindössze 0,6\%-os Spanyolországban volt [3]. A legutóbb közzétett, 1989 és 2013 közötti 25 éves időszakra vonatkozó eredmények a korábbinál kissé kedvezőbb, átlagosan évi 3,4\%-os incidencianövekedést igazoltak; az emelkedés 6,6\%-kal továbbra is a lengyel katowicei központban volt a leggyorsabb, 0,5\%-kal a spanyol katalóniai centrumban a leglassabb. Az incidencia időbeli változását elemezve kimutatható, hogy Európában a növekedés üteme 2004 és 2008 között átmenetileg lassult, 2009-től azonban visszatért a korábbi érték közelébe.
A kontinensen belül a betegség gyakorisága még mindig széles határok között mozog, bár az utóbbi időben a különbségek fokozatosan csökkentek (1. ábra). A nagy kockázatú területeken, Észak-Európában és Szardínián, megtorpant az emelkedés, és úgy tưnik, hogy az incidencia platóértéket ért el, a közép- és kelet-európai régióban viszont gyorsult a növekedés [4]. A Magyar Gyermekdiabetes Regiszter 1989-ben alakult az EURODIABhálózat részeként. A felmérések szerint hazánkban az elmúlt évtizedekben a gyermekkori l-es típusú diabetes gyakorisága a természetes fluktuációtól eltekintve lineárisan nőtt. 2011-ben a 0-15 éves korcsoportban a standardizált incidencia 20,0 eset/100 000 fó volt, ami 1,6 eset/1000 fó prevalenciaértéknek felelt meg [1]. A legfrissebb hazai epidemiológiai elemzés 2016-ban a 0-18 éves korcsoportra vonatkozóan 23,0 eset/100 000 fo// év incidenciát és 2,09 eset/1000 fó prevalenciát igazolt [5].

A Nemzetközi Diabetes Szövetség (International Diabetes Federation, IDF) legutóbbi adatközlése szerint 2019-ben 600 900, 15 év alatti gyermek élt l-es típusú diabetesszel világszerte, az új esetek száma pedig évi 98 200-ra volt becsülhető. A beteg gyermekek több mint egynegyede $(27,0 \%, 162600$ fó) Európában, egyötöde $(20,0 \%, 121400$ fó) az észak-amerikai régióban él. A népességszámra vetített gyakoriság tekintetében Finnország, Svédország és Kuvait vezeti a listát. Bár a legnagyobb incidenciájú 10 országból 6 jelenleg európai (2. ábra), ma már a legtöbb új esetet Indiában, az Amerikai Egyesült Államokban és Brazíliában diagnosztizálják, és a legtöbb l-es típusú cukorbeteg gyermek is e

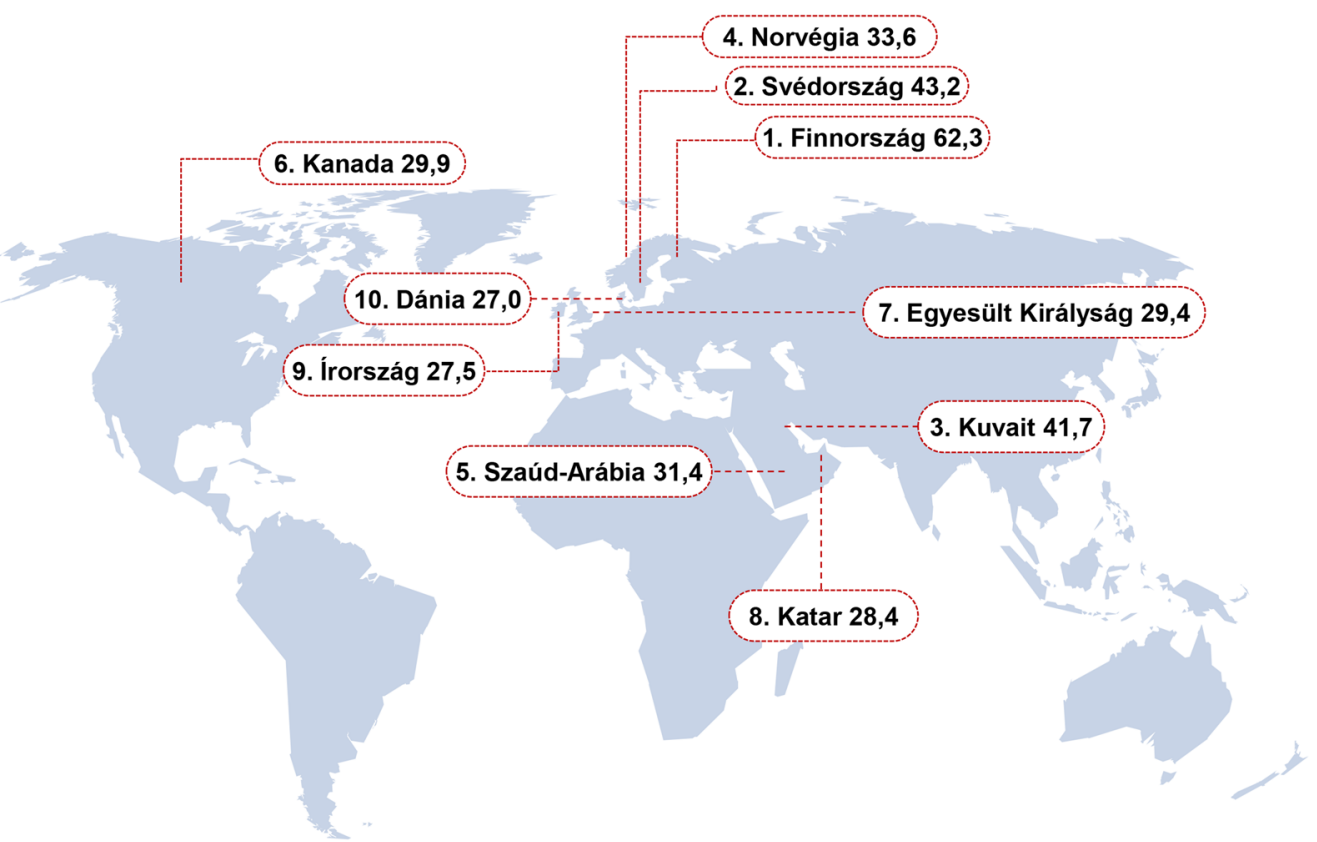

2. ábra A gyermekkori 1-es típusú diabetes incidenciarátáját tekintve a listavezető országok (eset/100 000 fö/év, IDF Atlas 2019)
Az ábra a [6] referencia felhasználásával készült 


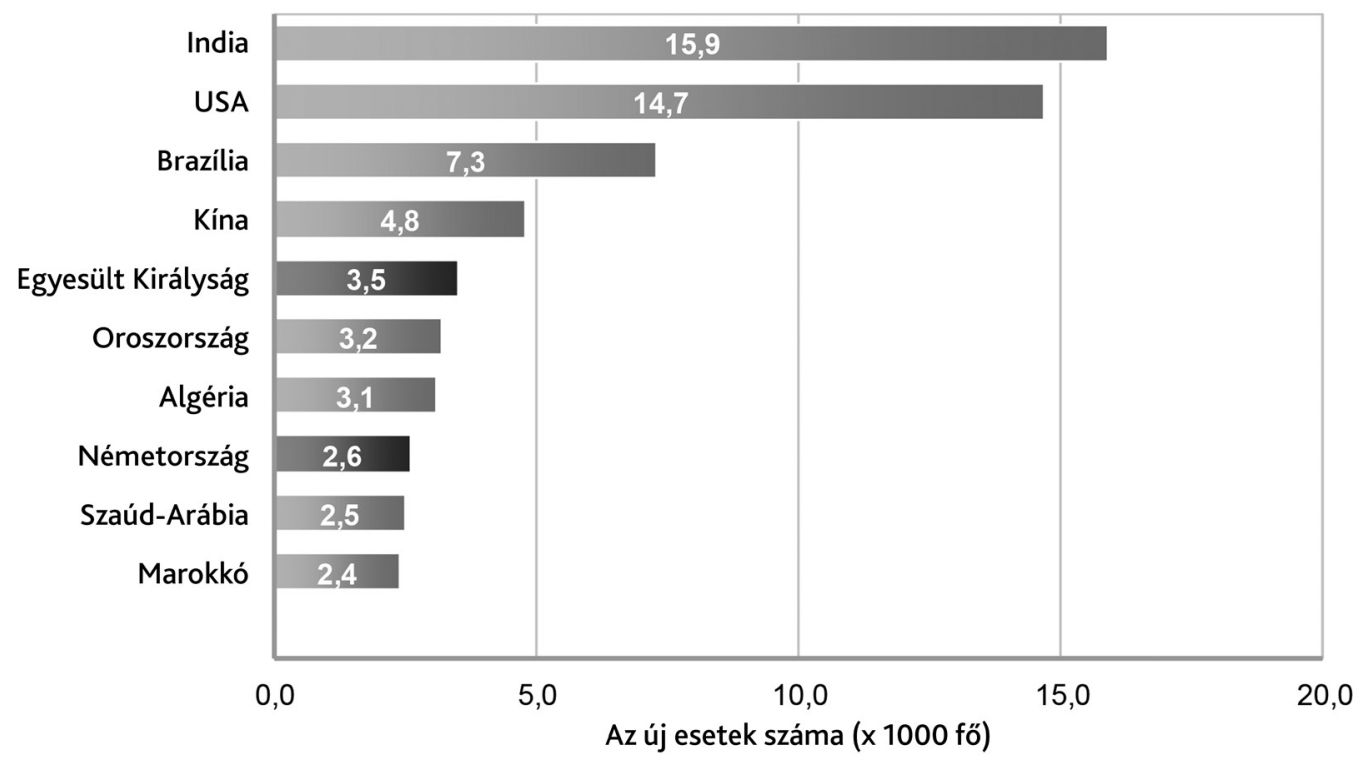

\begin{tabular}{l|l} 
3/A ábra & $\begin{array}{l}\text { A gyermekkori l-es típusú diabetes új eseteinek incidenciáját tekintve a listavezető országok (IDF Atlas 2019) } \\
\text { Az ábra a [6] referencia felhasználásával készült }\end{array}$
\end{tabular}

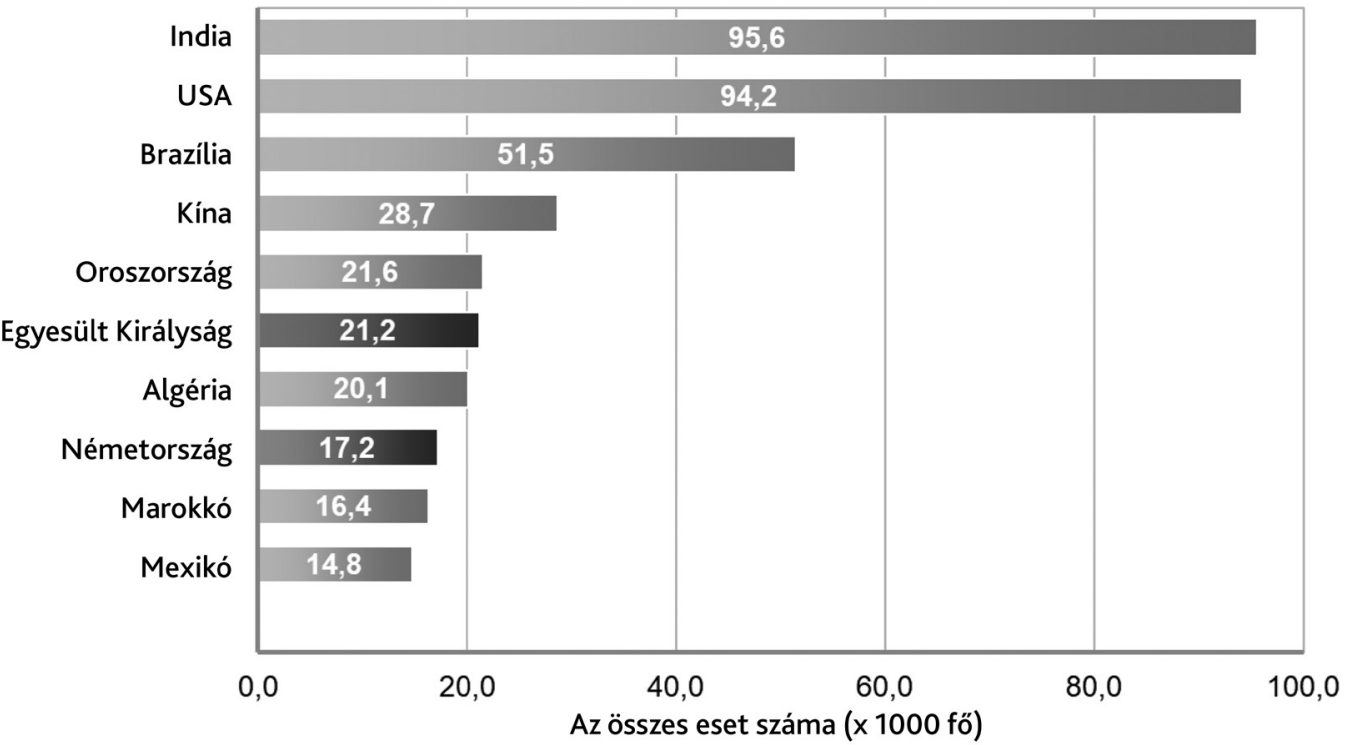

\begin{tabular}{l|l} 
3/B ábra & $\begin{array}{l}\text { A gyermekkori l-es típusú diabetes prevalenciáját tekintve a listavezető országok (IDF Atlas 2019) } \\
\text { Az ábra a [6] referencia felhasználásával készült }\end{array}$
\end{tabular}

nagy népességú országokban él a világon $(3 / A$ és $3 / B$ ábra) [6].

A földrajzi különbségek feltárásakor az l-es típusú diabetes gyakoriságának éghajlat szerinti megoszlását is megvizsgálták: a legnagyobb gyakoriságot az óceáni területeken írták le, ezt a kontinentális, a sivatagi és a mediterrán éghajlat követte, míg a legkevesebb esetet rendre a forró éghajlati övezetekben észlelték (4. ábra). Az északi féltekén az Egyenlítőtől a sarkkör felé haladva a magasabb szélességi körök mentén a napsütés időtartamának csökkenésével fordított arányban nőtt az incidencia [7]. A földrajzi variabilitást szemlélve a legszembetúnőbb megállapítás, hogy az l-es típusú cukorbetegség gyakorisága az északi területeken sokkal nagyobb, mint az Egyenlító környékén. Ez a mintázat regionálisan is kimutatható: Európán belül az északi és északnyugati országokban (Finnország, Svédország, Észak-Írország) a legmagasabb, a déli és a keleti régióban (Macedónia [mai nevén: Észak-Macedónia], Olaszország Marche régiója, Románia) a legalacsonyabb az incidencia [4]. Bár az észak-déli gradiens látszólag egyértelmú, a részletes adatelemzések az azonos szélességi körön elhelyezkedő országok incidenciaadatai között jelentős különbségeket tártak fel (ld. Észak-Írország és Lengyelország), és a déli területeken is találtak regionálisan nem illeszkedő „diabetes-forrópontokat” (ld. Szardínia, Kuvait, Szaúd-Arábia vagy Katar) (2. ábra). 


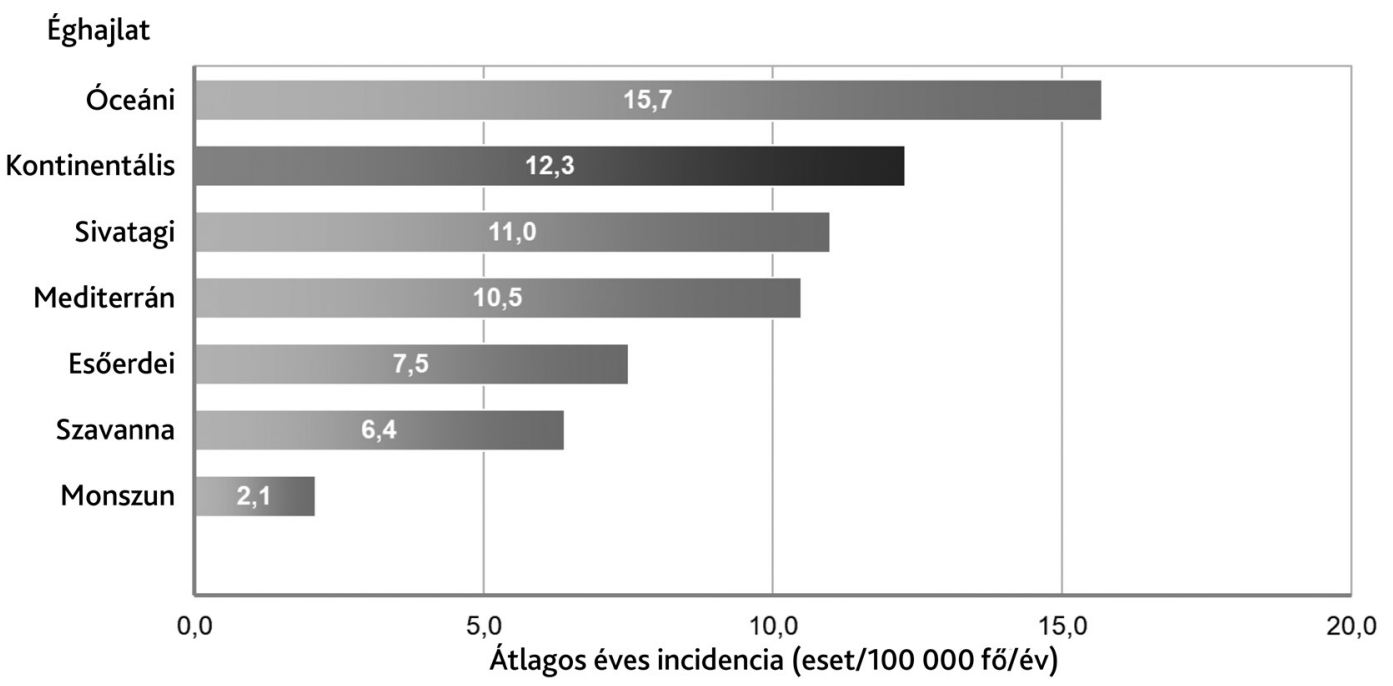

\begin{tabular}{l|l} 
4. ábra & $\begin{array}{l}\text { A gyermekkori l-es típusú diabetes átlagos éves incidenciája } 1965 \text { és } 2012 \text { között, éghajlatok szerinti megoszlásban } \\
\text { Az ábra a [7] referencia felhasználásával készült }\end{array}$
\end{tabular}

Az l-es típusú diabetesszel kapcsolatos etiológiai kutatások - az autoimmun hajlamot kialakító genetikai háttér mellett - évtizedek óta elsősorban a feltehetóleg betegségirányú progressziót kiváltó környezeti faktorokra fókuszálnak [8]. A számos feltételezett kockázati tényező közül a kezdeti vizsgálatok jórészt a lehetséges vírusinfekciókra és a táplálkozási faktorokra (anyatejes vs. tehéntejalapú táplálás) vonatkoztak. A kutatási eredményeknek köszönhetően a vírusoknak az l-es típusú diabetes patogenezisében betöltött összetett szerepe egyre pontosabban körvonalazódik. Az infektín modell szerint bizonyos vírusfertőzések (például rubeóla, cytomegalovirus) az esetek egy részében közvetlenül a $\beta$-sejteket érintik, ami a szigetekben „citokinvihart” és sejtszétesést vált ki, ez pedig gyorsan az inzulintermelő képesség megszünéséhez és autoimmun 1-es típusú diabetes kialakulásához vezet. A molekuláris mimikri modellje szerint krónikus vagy rekurráló fertőzés során a $\beta$-sejt-fehérjékhez hasonló aminosav-szekvenciával rendelkező vírussal fertőzött sejt ellen indul el a primer immunválasz; később a molekuláris hasonlóság miatt a $\beta$-sejtek is „célponttá” válnak az autoreaktív T-sejtek számára, érzékenyítődnek a sejthalálra, vagy a nagyobb endoplazmatikus reticulum stressz következtében fokozatosan múködési zavar lép fel [9]. Számos vírus (például entero-, herpesz-, parecho-, rota- és retrovírusok) provokáló szerepét sikerült bizonyítani, melyek közül néhány etiológiai jelentősége a hatékony védőoltásnak köszönhetően ma már sok helyen elhanyagolható (ld. mumpsz és rubeóla) [10]. Más kórokozók, így az enterovírusok által okozott fertőzés ma is gyakori gyermekkorban, és bár e törzsek igen változékonyak, 8-10 évente lecserélődnek; „diabetogén tulajdonságuk” feltehetőleg a stabil genomikus régiójukban helyezkedik el, azaz a vírusevolúció során továbbvivődik. A higiéniabipotézis szerint azokban az országokban, ahol ritkább az enteroví- rus-fertőzés a háttér-populációban (például Finnország), csökken a transzplacentárisan átadott protektív anyai antitestek szintje, és/vagy a csecsemők későbbi életkorban találkoznak az enterovírusokkal, amikor már nincs jelen anyai védő immunglobulin. Ugyanakkor az adatbáziselemzések nem támasztják alá egyértelmúen ezt a feltételezést [11].

A csecsemótáplálási elmélet szerint a tehéntejben, illetve a tehéntejalapú tápszerekben jelen levő fehérjék (bovininzulin, bovin-szérumalbumin, kazein, $\beta$-laktalbumin) átjutnak a még éretlen tápcsatornán (áteresztő bél, 'leaky gut'), és a keringésbe kerülve idegen antigénként aktiválják a később autoreaktívvá váló T-lymphocytákat [12]. Két nagy prospektív táplálkozási tanulmány közül azonban a TRIGR (Trial to Reduce IDDM in the Geneticalyly at Risk) nem talált összefüggést a korai tehéntejtáplálás és az l-es típusú diabetes között [13], és a FINDIA (Finnish Dietary Intervention Trial for the Prevention of Type 1 Diabetes) vizsgálat sem igazolta, hogy a bovininzulin-mentesített tápszerrel meg lehetne előzni a szigetsejt elleni autoimmunitás kialakulását [14].

Az elmúlt évtized felfedezése, hogy számos környezeti hatás (például csecsemőtáplálás, császármetszés, korai antibiotikumhasználat) a humán mikrobiom fejlődésének és múködésének módosításán keresztül befolyásolhatja az 1-es típusú diabetes kockázatát [11]. Kísérleti adatok azt sugallják, hogy a bélmikrobiota és a gazdaszervezet veleszületett immunitása közötti párbeszéd szorosan kapcsolódik a pancreas- $\beta$-sejtek T-sejt mediálta destrukciójához. Kimutatták, hogy a cukorbeteg gyermekek mikrobiom-összetétele más (a Bacteroidetes fajok száma nagyobb, a Firmicutes törzsé kisebb), mint az anyagcsere-egészséges kontrolloké. A Gram-pozitív baktériumok sejtfalának bioszintézisét gátló vankomicin megváltoztatta az újszülött egerek belének korai mikrobiális kolonizációját, aminek következményeként csök- 
kent a diabeteshajlam a kezeletlen kontrollokhoz képest. A fermentálható rosttól mentes diétával táplált NODegerek kifejezetten védettek voltak a rostdús, félszintetikus táplálékkal etetett társaik megnövekedett diabeteskockázatával szemben. Ezt a tapasztalást összefüggésbe hozták a bélmikrobiota összetételének megváltozásával, mivel a rostdús étrend mellett szignifikánsan nőtt a Bacteroidetes, és csökkent a Firmicutes fajok száma. A fermentálható rostok (különösen a pektin és a xilán) magas diabetogén potenciálja valószínúleg a proinflammatorikus és stresszgének vastagbélbeli expressziójának fokozásával áll kapcsolatban. A bélmikrobiota és a természetes immunitás kölcsönhatása kulcsfontosságú szerepet játszik az l-es típusú diabetes iránti hajlam epigenetikai modulálásában. A higiéniahipotézis magyarázata pedig az lehet, hogy a korai csecsemőkorban mind a patogén, mind a szimbióta mikrobákkal való kisebb mértékű találkozás akadályozza az immunrendszer természetes fejlődését, és a hibás szuppresszor T-sejt indukciója az autotolerancia elvesztéséhez vezet [15].

A földrajzi különbségeket és a klimatikus hatásokat összegezve úgy tûnik, hogy az l-es típusú diabetes az északi szélesség 40-60. foka között, óceáni éghajlaton, alacsonyabb átlaghőmérséklet és kevesebb napsütéses időtartam mellett a leggyakoribb. Az eltérő klímaviszonyok - feltehetóleg az ultraviola sugárzás regionális különbségén keresztül - befolyásolják a D-vitamin-képződést. A D-vitamin fontos szerepet játszik az immunrendszer szabályozásában: az adaptív immunválaszt elnyomja, a veleszületettet serkenti; hiányakor a T-helper-1-immunválasz downregulációja csökken, ami hozzájárulhat az autoimmun folyamatok elindításához [16]. Bár az elmúlt évtized egyik legnépszerúbb patogenetikai hipotézise, a D-vitamin-hiány-elmélet számos ponton jól használható az 1-es típusú cukorbetegség incidenciájában megjelenő klímahatások és földrajzi különbségek magyarázatára, több ellentmondás is övezi. A világ elsó számú „diabetes-forrópontjára”, Finnországra évtizedek óta a kiugróan magas gyakoriság mellett is állandó esetszám-növekedés volt jellemző, majd 2006-ban az incidencia platófázist ért el (64,9 eset/100 000 fó). Az azóta tapasztalható stagnálás egyik lehetséges okának a néhány évvel korábban általánosan bevezetett, korai és folyamatos D-vitamin-pótlást vélik [17]. Ugyanakkor a csecsemókori D-vitamin-pótlás ma már egész Észak-Európában megvalósul, így az egyes területek között továbbra is fennálló incidenciakülönbségek miatt a D-vitamin-hiány nem tekinthető általános trigger tényezőnek a $\beta$-sejt elleni autoimmunitás elindításában. Ráadásul két nagy prospektív obszervációs vizsgálat, a DAISY (Diabetes Autoimmunity Study in the Young) és az ABIS (All Babies in Southeast Sweden) sem talált kapcsolatot a csecsemőkori táplálás $\mathrm{D}$-vitaminnal való kiegészítése és a szigetsejtellenes autoimmunitás vagy a cukorbetegségirányú progresszió között $[18,19]$. A D-vitamin és az l-es típusú diabetes összefüggésének vizsgálata kapcsán felmerült a kóros D-vitamin-receptor (VDR) patogene- tikai szerepének lehetősége is. A VDR rendellenessége gyakran csökkent melaninképződéssel társul, ami magyarázhatja azt a megfigyelést, hogy mind az északi népcsoportok, mind a szardíniaiak esetén gyakoribb a világos bőrű és kék szemű egyének között az l-es típusú cukorbetegség a sötétebb bőrtónusú és szemszínú kontrollokhoz képest. A VDR tulajdonképpen egy nagy affinitású, ligand által aktivált transzkripciós faktor, mely a D-vitamin kötődését követően a retinoid X-receptorral (RXR) heterodimert képezve aktiválja az RNS-polimeráz-II-t, és ezáltal különböző nukleáris proteinek képződését katalizálja. Kimutatták, hogy a pancreasban a VDR a Ca-beáramlás szabályozása révén képes befolyásolni az inzulinelválasztás mértékét. Finnországban ugyanakkor részletes vizsgálatokat végeztek az l-es típusú diabetesesek körében feltételezetten nagyobb gyakorisággal előforduló kóros D-vitamin-receptor kimutatására, sikertelenül [20].

Szardínia szigetén az l-es típusú diabetes incidenciája a 20. század második felében kezdett meredeken emelkedni, és vált 2009-ben a finnországi után a második legmagasabbá (44,8 eset/100 000 fó/év; ez ötszöröse volt az akkor Olaszország kontinentális részein észleltnek). Ez időben egybeesett a Szardínián évszázadok óta tartó endémiás maláriafertőzésnek a nagy mennyiségű DDTvel (diklór-difenil-triklóretán) történt felszámolásával. Mivel nincs a világon másik olyan maláriaendémiás terület, ahol a fertózést ilyen gyorsan és agresszíven eradikálták volna, sajnos nincs összehasonlításra alkalmas adat annak a hipotézisnek a tesztelésére, hogy a malária előfordulásának gyors csökkentése és/vagy a DDT-használat kapcsolatban állhat-e a diabetes előfordulásának hirtelen megemelkedésével [16]. A szardíniai szarvasmarha-állomány közel 60\%-a Mycobacterium avium paratuberculosissal (MAP) van átfertőződve; a kórokozó előfordulhat pasztőrözött tejtermékekben is, és tünetmentesen átterjedhet az emberekre. A $\beta$-sejt-károsodás lehetséges okaként lényegesen ritkábban tárgyalt baktériumfertőzések közül a MAP esetén már korábban feltételezték, hogy oki szerepet játszhat az l-es típusú diabetes kialakulásában, hiszen sikerült a betegek vérében a kórokozó DNS-ét kimutatni; ráadásul a MAP hősokkproteinjének (HSP65) és a hasnyálmirigy glutaminsav-dekarboxiláz (GAD65) enzimjének aminosavszekvenciája részben azonos, így a kórokozóval szembeni immunválasz megtámadhatja a gazdaszervezetet is (ld. molekuláris mimikri). Bár a szardíniai vizsgálatok alátámasztották, hogy a MAP-fertőzés hozzájárulhatott a cukorbetegség gyakoriságának fokozódásához, ez önmagában természetesen nem magyarázza az incidenciarobbanást [16]. Később Szardínia egyedi geokémiai profiljára, a talaj- és légszennyezettségen keresztül a lakosság nehézfémeknek való kitettségére terelődött a figyelem. Állatkísérletes adatok igazolják, hogy bizonyos nehézfémek tartós expozíciója (például higany, króm, ólom, kadmium, arany, ezüst) az immunfunkciók módosítása révén autoimmunitást indukálhat. A szardíniai ökológiai elemzésekben 
viszont a kobalt, a réz, a mangán, a nikkel és a cink szintje fordítottan volt arányos az l-es típusú diabetes előfordulásával, ami alapján felmerül e nehézfémek esetleges védőszerepe. Az említettek közül a cinkkel kapcsolatban áll rendelkezésre a legtöbb adat. A cink nélkülözhetetlen nyomelemként szerepet játszik az inzulintermelésben, védi a $\beta$-sejteket a citokin mediálta destrukcióval szemben, a vázizomban és a zsírszövetben található cinkfüggó molekula (IRAP, insulin-regulated aminopeptidase) aktív glükóztranszporterként fokozza e szövetek cukorfelvételét. 1-es típusú cukorbetegségben a cinkhomeosztázis zavarára utalhat az észlelt fokozott intestinalis cinkürítés és az egészséges kontrollokhoz képest alacsonyabb szérumszint is [16]. További bizonyítékul szolgál egy korábbi tanulmány, amelyben összefüggést találtak az ivóvíz alacsonyabb cinktartalma és az l-es típusú diabetes megnövekedett kockázata között [21], rágcsálómodellekben pedig a cink az NF-kappa-B-útvonal szabályozójaként a betegség egyik prevenciós célpontjának számít [22].

Az 1-es típusú cukorbetegséggel kapcsolatba hozott vegyi anyagok és a természetben előforduló mikotoxinok listája hosszú, a tanulmányok eredményei ellentmondásosak. Mindezek tisztázására a közelmúltban Angliában nagyszabású ökológiai kutatást végeztek, melynek során a vizsgált 53 kockázati tényező közül mindössze néhány környezeti (szálló por, nitrogén-dioxid, nitrogén-oxidok, szén-monoxid, talaj-ólomtartalom, éjszakai kültéri fény) és demográfiai hatás (túlzsúfoltság, népsűrüség, etnikum) mutatott összefüggést az l-es típusú diabetesszel, de a többváltozós regressziós elemzésben már csak a radonsugárzás és a többszörös deprivatiós index (IDM, index of multiple deprivation: a foglalkoztatás, a lakhatás, a jövedelem, a képzettség, az egészség, a bünözés és a lakókörnyezet dimenziója mentén képzett mutató) esetén maradt statisztikailag szignifikáns a kapcsolat [23].

Hasonlóan ellentmondásosak az adatok a védőoltásoknak az autoimmunitást indukáló lehetséges szerepére vonatkozóan. A 23 tanulmányt összesítő metaanalízis arra a következtetésre jutott, hogy a vizsgált 16 vakcina nem növeli a gyermekkori 1-es típusú cukorbetegség kockázatát [24]. Sőt a BCG-oltás olyan potenciális immunmodulátorként keltette fel az érdeklődést, amely elméletileg csökkentheti az autoimmun hajlamot. Sajnos a klinikai adatok nem mutattak összefüggést a BCG-oltás és a $\beta$-sejt elleni autoimmunitás vagy az 1 -es típusú diabetes kialakulása között [11].

\section{Etnikai eltérések}

Az l-es típusú diabetes előfordulásának etnikai befolyásoltságát egyes népcsoportok tartósan alacsony incidenciarátája (ld. Japán: 2,0; Kína-Sanghaj: 3,1; Tajvan: 5,0 eset/100 000 fó/év) és a soknemzetiségü országokra jellemző jelentős gyakoriságbeli különbségek is alátámasztják (ld. Egyesült Államok, ahol a fehér fiatalok kö- rében nyolcszor magasabb a gyermekkori l-es típusú cukorbetegség prevalenciája, mint az öslakos indiánok között [2,55 vs. 0,35 eset/1000 fó]) [25-27]. Az ázsiai populációban mért alacsony előfordulás részben biztosan genetikai okokra vezethető vissza, hiszen az l-es típusú diabetes fó determinánsának, a humán leukocytaantigén (HLA) rendszerének Ázsiában az európai népességtől eltérő, speciális hajlamosító variánsa van, ami nemcsak az incidenciát, hanem a betegség lefolyását is befolyásolja (az ázsiai gyermekpopulációban az esetek harmadát speciális rapid, illetve lassú progressziójú diabetesformák teszik ki) [26, 28].

$\mathrm{Az}$ európai populáció genetikai állománya a többi kontinens népességével összehasonlítva homogénnek tekinthető, néhány kisebb, zárt közösségben azonban lehetnek jelentős különbségek. Ilyen kis létszámú, évtizedeken át izoláltan élő népcsoport alapította Szardíniát is. Megfigyelések szerint a Szardíniából kivándorlók körében a betegség incidenciája nem változik érdemben, bár manifesztálódása késik a szigeten lakókhoz képest, ami megerősíti, hogy a genetikai háttér is hozzájárulhatott az l-es típusú diabetes szardíniai „berobbanásához” [16]. Ugyanakkor ma már egyértelmúen látszik, hogy bár az 1-es típusú diabetes előfordulása világszerte jól korrelál a hajlamosító HLA-gének háttérpopuláció-beli gyakoriságával, a fó genetikai determináns jelentette kockázat mértéke folyamatosan csökken, ami szintén a környezeti terhelés fokozódását támasztja alá [29]. Ezt a feltételezést erősítik egyrészt a hasonló genetikai hátterü, de régóta eltérő földrajzi régióban élő közösségek esetén tapasztalt különbségek, másrészt a hosszú távon stabil genetikai állományú, zárt etnikai csoportokban, új lakóhelyen a diabetesincidenciában bekövetkező változások is. Az előbbire példa a döntően norvég származású vikingek által alapított Izland, ahol az l-es típusú diabetes gyakorisága jóval kisebb a Norvégiában észleltnél, vagy Észtország, ahol a hasonló etnikai összetétel ellenére az incidencia csak körülbelül negyede a finnországi értéknek. Az utóbbit olyan migrációs tanulmányok igazolják, amelyek szerint az eredeti lakóhelyről elvándorolt népcsoport körében az 1-es típusú cukorbetegség előfordulási gyakorisága a befogadó ország lakosainak értékéhez vált hasonlatossá. Ezt figyelték meg a Kanadába bevándorolt franciák és izraeliek körében, akiknél a diabetesrizikó két-háromszorosra nőtt, bár alacsonyabb maradt a befogadó kanadai populációra jellemzőnél, illetve az Angliában élő dél-ázsiai gyermekek esetén, akiknél a diabetesincidencia a megszokott ázsiai alacsony értékhez képest jelentősen megemelkedett, és megközelítette a fehér lakosság körében észleltet [30].

\section{Életkor és nem szerinti eltérések}

A korcsoport-specifikus elemzések szerint az 1-es típusú diabetes az iskoláskort megelőző években és serdülőkorban halmozódik. Az incidencia életkori megoszlásának kétcsúcsú mintázata mindkét nemre jellemző, a lányok- 
nál kissé korábban megjelenő peripubertalis csúccsal [30]. Bár az újonnan diagnosztizált esetek zöme a serdülőkorra tehető, az EURODIAB eredményei szerint Európában az incidencia évi növekedésének mértéke a legfiatalabb, 0-4 éves gyermekek körében a legmagasabb (5,0\%), az 5-9 éves gyermekek körében közepes $(3,7 \%)$, a 10-14 éves korosztályban a legalacsonyabb $(2,1 \%)$ [4]. Ausztráliából azonban ezzel ellentétes megfigyelésról számoltak be: a 2000 és 2011 között stagnáló, standardizált éves incidenciaadatok mellett csak a 10-14 éves korosztályban igazoltak szignifikáns növekedést [31]. Magyarországon 1989 és 2009 között a betegség átlagos gyakorisága 12,5/100 000/év volt, ami évente átlagosan 4,4\%-kal nőtt. Az átlagos éves incidencianövekedés hazánkban az európai trendeknek megfelelően a legfiatalabb korosztályban volt a leggyorsabb (0-4 évesek: 6,2\%, 5-9 évesek: 4,9\%, 10-14 évesek: 3,3\%) [1].

$\mathrm{Az}$ elmúlt években több genetikai vizsgálat igazolta, hogy a magas kockázatú HLA-gén-variánsoknak az új diabeteses esetek kialakulásához való hozzájárulása az 5 évesnél fiatalabb korosztályban csökken a leginkább, és ebben a betegcsoportban a korábban protektív HLA-genotípusok védőhatásának mérséklődése is kimutatható. Ez azt jelzi, hogy az l-es típusú cukorbetegség incidenciája elsősorban az erôteljesebb környezeti hatások okozta penetranciaváltozás miatt növekszik ebben a korcsoportban, és nem a hajlamosító genotípusok „terjedése” miatt [32].

Megfigyelések szerint az autoimmun betegségek általában a nők között fordulnak elő gyakrabban, a gyermekkori l-es típusú diabetes incidenciája azonban a populációk döntő többségében közel azonos a két nemben. Az EURODIAB 26 központjából mindössze háromban (Finnország, Németország-Baden-Württemberg és Magyarország) mutattak ki szignifikáns különbséget a nemi megoszlásban, és mindegyik esetben a fiúk körében volt gyakoribb a betegség [4]. Ehhez hasonlóan a „diabetesforrópontnak" számító Szardínián is 31\%-kal több fiú volt érintett, mint azonos életkorú lány [33]. Ezzel szemben Japánban a 15 év alatti korosztályban konzekvensen a lányok között gyakoribb az l-es típusú diabetes [34]. A részletes adatelemzések eredménye úgy összegezhető, hogy az 1-es típusú cukorbetegségre vonatkozóan a nagy gyakoriságú népcsoportokban, illetve a serdülők és a fiatal felnőttek között egyértelmúen férfi-, az alacsonyabb incidenciájú régiókban inkább enyhe női dominancia észlelhető.

A nemek közötti heterogenitást eddig sem genetikai, sem környezeti okokkal nem sikerült magyarázni. A nemi kromoszómák részletes géntérképezése során az X-kromoszómán egyetlen minor hajlamosító génrégiót találtak (Xq28), az Y-kromoszómán egyet sem [35]. Érdekes megfigyelés, hogy Szardínián 1989 és 2009 között az l-es típusú diabetes incidenciája nem párhuzamosan nőtt a születésszámmal, és a születésikohorsz-hatás a lányok esetében korábban (0-5 éves korban) kezdődött, mint a fiúknál (5-10 éves korban), ezért felmerült egy, a lányok esetén korábban érvényesülő perinatalis (talán infektív) környezeti tényező szerepe, de ezt eddig nem sikerült bizonyítani $[16,33]$.

\section{Szezonalitás és ciklicitás}

A klinikai vizsgálatok során hamar felfigyeltek az l-es típusú diabetes manifesztálódásának szezonális változására. A legtöbb közlés szerint az új esetek megjelenésének csúcsa az őszi-téli hónapokra esik, amit az ezen időszakra tehető légúti vírusfertőzésekkel magyaráznak; több felső légúti kórokozó (például H1N1, H3N2, influenza B-vírus, parainfluenza-vírus) esetén már igazolták is az l-es típusú diabetes kockázatának növekedésével való patogenetikai kapcsolatot [4]. Egy másik hipotézis szerint ezekben az alacsonyabb átlag-hőmérsékletú, csapadékos hónapokban nagyobb a légszennyezés, és nő a talaj nehézfém-koncentrációja, ami hosszú távon szintén hozzájárulhat az autoimmun betegségek - köztük az 1-es típusú diabetes - gyakoribb előfordulásához [36].

$\mathrm{Az}$ irodalomban beszámolnak az incidencia évenkénti ciklikus változásáról is. A legkorábbi jelentés az 1978 és 1990 közötti időszakban az angliai Yorkshire regionális nyilvántartásából származik, amely négyévente jelzett nagyobb előfordulási csúcsot [37]. 1985 és 2010 között Nyugat-Ausztráliából [38], később 2000 és 2011 között a teljes ausztrál népességre vonatkozóan [31], 1989 és 2012 között Lengyelországból jelentettek az incidenciaadatokban ötévente [39], 1990 és 2007 között Északkelet-Angliából hatévente ismétlődő ciklusmintázatot [40]. Az EURODIAB-nak az 1989 és 2013 közötti időszakot felölelő elemzése során a 26 központból mindöszsze 4-ben figyeltek meg négyéves ciklusokat, az öt-, illetve hatéves mintázatot azonban egyik centrumban sem sikerült megerősíteni [4].

A ciklusos mintázat szórványos jellege a nagy pandémiák helyett inkább a kisebb közösségeket érintő, helyi járványokra utalhat. A diabetesincidencia négy-, öt- vagy hatéves periodicitását azonban nehéz magyarázni, mert jelenleg nem ismerünk olyan vírusfertőzést, sem klimatológiai tényezőt vagy más környezeti expozíciót, amely az l-es típusú cukorbetegség incidenciacsúcsaival szinkrónban rendszeresen ismétlődne.

\section{Következtetés}

Az elmúlt 50 év epidemiológiai vizsgálatai igazolták a gyermekkori kezdetú, l-es típusú diabetes előfordulási gyakoriságának folyamatos emelkedését. Az is nyilvánvalóvá vált, hogy bár az l-es típusú cukorbetegség kialakulásában az autoimmunitás primer kockázati tényezője a HLA-hoz kötött genetikai háttér, nem a genetikai terheltség populációszintű fokozódása okozza az incidencianövekedést, hanem a környezeti nyomás növekedése. Az évtizedek óta folyó intenzív kutatások ellenére azonban máig nem ismert a környezeti faktorok pontos szerepe. Valószínúleg lehetnek oki tényezők, a betegség ki- 
alakulását gyorsító akcelerátorok vagy épp ellenkezőleg, védőfaktorok, sôt akár a betegség patogenezisében egyszerre több ponton, több mechanizmussal is részt vehetnek. Bizonyosan oki és/vagy akcelerátori szerepe van egyes virális (és bakteriális) infekcióknak. A vírusetiológiát támasztja alá az l-es típusú diabetes incidenciájának időbeli (szezonalitás) és térbeli (geográfiai forrópontok) halmozódása, illetve a populációk keveredésével kapcsolatos demográfiai és társadalmi tényezőknek (például népsürüség, kivándorlás, túlzsúfoltság, szociális helyzet) a jelentősége is. Egy környezeti hatás érvényesülhet ugyan globálisan is (ld. klímaváltozás), mégis sokkal valószínúbb az a feltevés, hogy univerzális, minden beteg esetében kimutatható környezeti faktor nem létezik, inkább az adott „diabetogén” genetikai háttér által kialakított immun- és metabolikus miliővel interakcióba kerülő számos környezeti tényező közül egynek (vagy néhánynak) a specifikus hatása számít. Például bizonyos klímafeltételek egy adott földrajzi környezetben a D-vitaminhiány révén hajlamosíthatnak l-es típusú diabetesre, de megfelelő vitaminpótlás és fiziológiás D-vitamin-szint mellett is kialakulhat a betegség genetikai, akár a D-vitamin-metabolizmus egyéni variációi (például hibás konverziója kalcitriollá) és további környezeti tényezők társulása esetén.

Az elmúlt évek epidemiológiai tanulmányai rávilágítottak arra is, hogy a „hagyományos” környezeti faktorok időbeli és térbeli expozíciójának változásán túl új, a modern korra jellemző környezeti toxinok (például radioaktív hulladék, fényszennyezés), élelmiszerek és élelmiszer-adalékanyagok, háztartási vegyszerek, új fertőző ágensek, gyógyszerek megjelenésével és bizonyos demográfiai hatások felerősödésével is számolni kell. További érdekes felismerés a védő környezeti hatások lehetősége, melyek közül a klinikai gyakorlatban a leginkább a bélmikrobiomnak van jelentősége, hiszen az élő mikrobiomtörzsek vagy azok produktumai már a közeljövőben új terápiás ígéretet jelenthetnek.

A környezeti tényezők módosulása a gén-környezeti kölcsönhatások változásában is tetten érhető. Bebizonyították, hogy ma már kisebb genetikai rizikó is elegendő az l-es típusú cukorbetegség kialakulásához, de az is valószínú, hogy ezzel párhuzamosan újabb, korábban a diabeteshajlammal kapcsolatba nem hozott gének is szerephez jutnak a modern kori környezeti faktorok hatására. Ma már sejtjük, hogy az l-es típusú diabetes patomechanizmusa mennyire sokrétű, hiszen a különbözó hajlamosító génkombinációkat hordozó betegcsoportokban eltérő környezeti hatások elindíthatnak olyan alternatív molekuláris útvonalakat, melyek végeredménye a $\beta$-sejtek pusztulása. A betegség prevenciója csak akkor lesz sikeres, ha megtaláljuk e patogenetikai útvonalak közös, módosítható ellenőrző pontjait, ehhez pedig a genetikai és a környezeti faktorok minél pontosabb feltérképezése, a gén-környezeti kölcsönhatások dinamikus változásának nyomon követése szükséges.
Anyagi támogatás: A közlemény megírása anyagi támogatásban nem részesült.

Szerzôi munkamegosztás: L. K.: A szakirodalom kutatása, elemzése, az összefoglaló dolgozat megírása, szerkesztése. P. P., H. N.: A szakértői feladat ellátása, stilisztikai munkák elvégzése. A cikk végleges változatát mindhárom szerző elolvasta és jóváhagyta.

Érdekeltségek: A szerzőknek nincsenek érdekeltségeik.

\section{Irodalom}

[1] Gyûrûs É, Patterson C, Soltész Gy. "Constantly rising or peaks and plateaus?" Incidence of childhood type 1 diabetes in Hungary (1989-2009). [„Folyamatos emelkedő vagy csúcsok és fennsíkok?” A gyermekkori l-es típusú diabetes incidenciája Magyarországon (1989-2009).] Orv Hetil. 2011; 152: 16921697. [Hungarian]

[2] DIAMOND Project Group. Incidence and trends of childhood type 1 diabetes worldwide 1990-1999. Diabet Med. 2006; 23 : 857-866.

[3] Patterson CC, Dahlquist GG, Gyưrús É, et al. Incidence trends for childhood type 1 diabetes in Europe during 1989-2003 and predicted new cases 2005-2020: a multicentre prospective registration study. Lancet 2009; 373: 2027-2033.

[4] Patterson CC, Harjutsalo V, Rosenbauer J, et al. Trends and cyclical variation in the incidence of childhood type 1 diabetes in 26 European centres in the 25 year period 1989-2013: a multicentre prospective registration study. Diabetologia 2019; 62: 408-417.

[5] Barkai L, Kiss Z, Rokszin G, et al. Changes in the incidence and prevalence of type 1 and type 2 diabetes among 2 million children and adolescents in Hungary between 2001 and 2016 - a nationwide population-based study. Arch Med Sci. 2019; 16: 34-41.

[6] IDF Diabetes atlas. 9th edition. International Diabetes Federation, 2019. Available from: https://diabetesatlas.org/en/resources / [accessed: June 20, 2020]

[7] Chen YL, Huang YC, Qiao YC, et al. Climates on incidence of childhood type 1 diabetes mellitus in 72 countries. Sci Rep. 2017; 7: 12810 .

[8] Lukács K, Pánczél P, Hosszúfalusi N. Genetics of type 1 diabetes: present and future. [Az 1-es típusú diabetes genetikája: jelen és jövő.] Orv Hetil. 2017; 158: 1731-1740. [Hungarian]

[9] Dunne JL, Richardson SJ, Atkinson MA, et al. Rationale for enteroviral vaccination and antiviral therapies in human type 1 diabetes. Diabetologia 2019; 62: 744-753.

[10] Rodriguez-Calvo T, Sabouri S, Anquetil F, et al. The viral paradigm in type 1 diabetes: who are the main suspects? Autoimmun Rev. 2016; 15: 964-969

[11] Rewers M, Ludvigsson J. Environmental risk factors for type 1 diabetes. Lancet 2016; 387: 2340-2348.

[12] Li X, Atkinson MA. The role for gut permeability in the pathogenesis of type 1 diabetes - a solid or leaky concept? Pediatr Diabetes 2015 ; 16: 485-492.

[13] Writing Group for the TSG, Knip M, Åkerblom HK, et al. Effect of hydrolyzed infant formula vs conventional formula on risk of type 1 diabetes: The TRIGR randomized clinical trial. JAMA 2018; 319: 38-48.

[14] Vaarala O, Ilonen J, Ruohtula T, et al. Removal of bovine insulin from cow's milk formula and early initiation of beta-cell autoimmunity in the FINDIA pilot study. Arch Pediatr Adolesc Med. 2012; 166: 608-614.

[15] Lin L, Zhang J. Role of intestinal microbiota and metabolites on gut homeostasis and human diseases. BMC Immunol. 2017; 18: 2 . 
[16] Songini M, Mannu C, Targhetta C, et al. Type 1 diabetes in Sardinia: facts and hypotheses in the context of worldwide epidemiological data. Acta Diabetol. 2017; 54: 9-17.

[17] Mäkinen M, Simell V, Mykkänen J, et al. An increase in serum 25-hydroxyvitamin D concentrations preceded a plateau in type 1 diabetes incidence in Finnish children. J Clin Endocrinol Metab. 2014; 99: E2353-E2356.

[18] Simpson M, Brady H, Yin X, et al. No association of vitamin D intake or 25-hydroxyvitamin D levels in childhood with risk of islet autoimmunity and type 1 diabetes: the Diabetes Autoimmunity Study in the Young (DAISY). Diabetologia 2011; 54: $2779-2788$.

[19] Rosenbauer J, Herzig P, Giani G. Early infant feeding and risk of type 1 diabetes mellitus - a nationwide population-based casecontrol study in pre-school children. Diabetes Metab Res Rev 2008; 24: 211-222.

[20] Turpeinen H, Hermann R, Vaara S, et al. Vitamin D receptor polymorphisms: no association with type 1 diabetes in the Finnish population. Eur J Endocrinol. 2003; 149: 591-596.

[21] Samuelsson U, Oikarinen S, Hyöty H, et al. Low zinc in drinking water is associated with the risk of type 1 diabetes in children. Pediatr Diabetes 2011; 12: 156-164.

[22] Ho E, Quan N, Tsai YH, et al. Dietary zinc supplementation inhibits $\mathrm{NF}_{\kappa} \mathrm{B}$ activation and protects against chemically induced diabetes in CDl mice. Exp Biol Med (Maywood). 2001; 226: $103-111$

[23] Sheehan A, Freni Sterrantino A, Fecht D, et al. Childhood type 1 diabetes: an environment-wide association study across England. Diabetologia 2020; 63: 964-976.

[24] Morgan E, Halliday SR, Campbell GR, et al. Vaccinations and childhood type 1 diabetes mellitus: a meta-analysis of observational studies. Diabetologia 2016; 59: 237-243.

[25] Mayer-Davis EJ, Dabelea D, Lawrence JM. Incidence trends of type 1 and type 2 diabetes among youths, 2002-2012. N Engl J Med. 2017; 377: 301

[26] Mayer-Davis EJ, Kahkoska AR, Jefferies C, et al. ISPAD Clinical Practice Consensus Guidelines 2018: definition, epidemiology, and classification of diabetes in children and adolescents. Pediatr Diabetes 2018; 19(Suppl 27): 7-19.

[27] Dabelea D, Mayer-Davis EJ, Saydah S, et al. Prevalence of type 1 and type 2 diabetes among children and adolescents from 2001 to 2009. JAMA 2014; 311: 1778-1786.

[28] Kawabata Y, Ikegami H, Kawaguchi Y, et al. Asian-specific HLA haplotypes reveal heterogeneity of the contribution of HLA-DR and -DQ haplotypes to susceptibility to type 1 diabetes. Diabetes 2002; 51: 545-551.
[29] Hermann R, Bartsocas CS, Soltész Gy, et al. Genetic screening for individuals at high risk for type 1 diabetes in the general population using HLA class II alleles as disease markers. A comparison between three European populations with variable rates of disease incidence. Diabetes Metab Res Rev. 2004; 20: 322-329.

[30] Soltész Gy. Etiopathogenesis of type 1 diabetes. In: Halmos T, Jermendy Gy. (eds.) Diabetes mellitus. [Az l-es típusú diabetes etiopatogenezise. In: Halmos T, Jermendy Gy. (szerk.) Diabetes mellitus.] Medicina Könyvkiadó, Budapest, 2002; pp. 227-237. [Hungarian]

[31] Haynes A, Bulsara MK, Bower C, et al. Regular peaks and troughs in the Australian incidence of childhood type 1 diabetes mellitus (2000-2011). Diabetologia 2015; 58: 2513-2516.

[32] Hermann R, Knip M, Veijola R, et al. Temporal changes in the frequencies of HLA genotypes in patients with type 1 diabetes indication of an increased environmental pressure? Diabetologia 2003; 46: 420-425.

[33] Bruno G, Maule M, Biggeri A, et al. More than 20 years of registration of type 1 diabetes in Sardinian children: temporal variations of incidence with age, period of diagnosis, and year of birth. Diabetes 2013; 62: 3542-3546.

[34] Onda Y, Sugihara S, Ogata T, et al. Incidence and prevalence of childhood-onset type I diabetes in Japan: the TID study. Diabet Med. 2017; 34: 909-915.

[35] Barrett JC, Clayton DG, Concannon P, et al. Genome-wide association study and meta-analysis find that over 40 loci affect risk of type 1 diabetes. Nat Genet. 2009; 41: 703-707.

[36] Songini M, Lombardo C. The Sardinian way to type 1 diabetes. J Diabetes Sci Technol. 2010; 4: 1248-1255.

[37] Staines A, Bodansky HJ, Lilley HE, et al. The epidemiology of diabetes mellitus in the United Kingdom: the Yorkshire Regional Childhood Diabetes Register. Diabetologia 1993; 36: 12821287.

[38] Haynes A, Bulsara MK, Bower C, et al. Cyclical variation in the incidence of childhood type 1 diabetes in Western Australia (1985-2010). Diabetes Care 2012; 35: 2300-2302.

[39] Chobot A, Polanska J, Brandt A, et al. Updated 24-year trend of type 1 diabetes incidence in children in Poland reveals a sinusoidal pattern and sustained increase. Diabet Med. 2017; 34: 12521258 .

[40] McNally RJ, Court S, James PW, et al. Cyclical variation in type 1 childhood diabetes. Epidemiology 2010; 21: 914-915.

(Lukács Krisztina dr., Budapest, Szentkirályi u. 46., 1088 e-mail: krisztinalukacs@hotmail.com)

A cikk a Creative Commons Attribution 4.0 International License (https://creativecommons.org/licenses/by/4.0/) feltételei szerint publikált Open Access közlemény, melynek szellemében a cikk bármilyen médiumban szabadon felhasználható, megosztható és újraközölhetö, feltéve, hogy az eredeti szerző és a közlés helye, illetve a CC License linkje és az esetlegesen végrehajtott módosítások feltüntetésre kerülnek. (SID_1) 